\title{
Attitudes of nursing professionals towards suicidal behavior: influence of emotional intelligence
}

$\mathrm{M}^{\mathrm{a}}$ Carmen Carmona-Navarro ${ }^{1}$

$\mathrm{M}^{\mathrm{a}}$ Carmen Pichardo-Martínez ${ }^{2}$

\begin{abstract}
Objective: To assess attitudes and the influence of emotional intelligence is the objective of this work. Method: Nursing professionals answered a questionnaire that assessed the attitude towards suicide and emotional intelligence. Results: The results show a general adverse attitude towards suicidal behavior. The moral dimension of suicide makes the differences between mental health and emergency professionals. Conclusions: Possessing a higher degree of mental health training and a high level of emotional intelligence is associated with a more positive attitude towards patients with suicidal behavior. The formation and development of emotional skills are essential for care delivery to patients with suicidal behavior.
\end{abstract}

Descriptors: Nursing Professional; Emergency; Mental Health; Attitude; Emotional Intelligence; Suicide Attempt.

${ }^{1}$ RN, MSc, España.

2 PhD, Full Professor, Universidad de Granada, España.

Corresponding Author:

Carmen Carmona-Navarro

Dpto. Psicología Evolutiva y de la Educación

Facultad de Ciencias de la Educación

18071, Granada, España

E-mail: carmonamc42w@hotmail.com 


\title{
Atitudes do profissional de enfermagem em relação ao comportamento suicida: influência da inteligência emocional
}

Objetivo: avaliar a atitude e a influência da inteligência emocional é o objetivo deste trabalho. Método: profissionais de enfermagem responderam a um questionário para avaliar as atitudes suicidas e inteligência emocional. Resultados: os resultados mostram atitude geralmente desfavorável perante o comportamento suicida. A dimensão moral do suicídio faz a diferença entre profissionais de saúde mental e emergência. Conclusões: possuir maior grau de formação em saúde mental e alto nível de inteligência emocional associa-se a uma atitude mais positiva em relação ao paciente com comportamento suicida. A formação e o desenvolvimento de competências emocionais são essenciais para o cuidado dos pacientes com comportamento suicida.

Descritores: Enfermagem Profissional; Saúde Mental; Emergências; Atitude; Inteligência Emocional; Tentativa de Suicídio.

\section{Actitudes del profesional de enfermería hacia el comportamiento suicida: influencia de la inteligencia emocional}

\begin{abstract}
Objetivo: Evaluar la actitud y la influencia de la inteligencia emocional es el objetivo de este trabajo. Método: Profesionales de enfermería contestaron un cuestionario que evaluó la actitud hacia el suicidio e inteligencia emocional. Resultados: Los resultados muestran una actitud general desfavorable hacia el comportamiento suicida. La dimensión moral del suicidio marca las diferencias entre los profesionales de salud mental y urgencias. Conclusiones: Poseer un mayor grado de formación en salud mental y un alto nivel de inteligencia emocional se asocia a una actitud más positiva hacia el paciente con comportamiento suicida. Formación y desarrollo de habilidades emocionales son fundamentales para el cuidado de los pacientes con conducta suicida.

Descriptores: Profesional de Enfermería; Urgencias; Salud Mental; Actitud; Inteligencia Emocional; Tentativa de Suicidio.
\end{abstract}

\section{Introduction}

Suicide is considered a severe public health problem around the world, with almost one million cases per year and an estimated six people who are directly affected by each death. The psychological, social and economic impact of suicide on the family and community cannot be measured(1). Based on current trends, it is estimated that, globally, deaths by suicide will reach 1.53 million people by 2020, and a number of suicide attempts between ten and twenty times higher(2).

Multiple factors cause suicidal behavior, including biological, socio-environmental and psychological factors, each of which has a specific weight, and none of them separately may be sufficient to explain such behaviors by itself. From a health perspective, this is about secondary prevention, with increased survival and reduced morbidity and mortality rates after a suicide attempt. It is estimated that, for every consumed case of suicide, suicide attempts have led to five hospitalizations and 22 visits to emergency services ${ }^{(3)}$.

Few data have been collected with proper rigor about suicide attempts in different countries, so that the actual range of suicide attempts is unknown. One of the best places to collect data on suicide attempts and their characteristics is in hospital emergency services, although it is estimated that only a minimal part of people who attempt to commit suicide contact a public hospital. When people cannot treat their selfinflicted injuries by themselves and privately, they turn to the health system for help. Nursing professionals at the emergency service tend to be patients' first health contact after a suicide attempt or an episode of selfinjury. Appropriate evaluation and management of these patients is fundamental to prevent future suicidal behaviors. Health professionals frequently adopt a 
negative attitude towards these patients though, with a lack of interpersonal skills for care delivery and inappropriate patient evaluation ${ }^{(4)}$.

Ninety percent of people who commit suicide have diagnosable and treatable psychiatric disorders ${ }^{(4)}$, which is why prevention efforts should focus on patients with mental illnesses. Health professionals tend to divide mental and physical problems though, leading to fragmented client care and devaluation of mental patients' needs(5).

Stigmatizing attitudes influence the care and treatment patients receive negatively(6) and, moreover, they influence the care receivers' psychology and wellbeing, acting as a considerable obstacle in the search for help, treatment access, adherence and efficacy. Studies demonstrate common prejudices among physicians and nursing professionals towards patients who injure themselves, describing them as manipulators and attention callers ${ }^{(7)}$.

One of the main reasons mental patients identify not to seek professional help or not to keep up their treatment is stigma, and they consider that the health staff contributes to stigma and discrimination ${ }^{(8)}$.

Nursing professionals' work is surrounded by feelings and emotions, which are sometimes difficult to classify and identify and originate in patients as well as professionals. The psychological burden present in daily nursing affects these professionals' quality of life and work $^{(9)}$. Identifying these emotions and learning how to cope with them supposes gaining new tools to accomplish nursing work successfully.

Emotional Intelligence is the ability to acknowledge, understand and regulate one's own and other people's emotions, distinguish among them and use this information to guide one's thoughts and actions ${ }^{(10)}$. The benefits of emotional intelligence have been demonstrated in different contexts of daily life and in professional activities. Emotionally intelligent people display better physical and mental health, higher levels of wellbeing and vital satisfaction, less risk conducts, such as drugs use, and better interpersonal and social relations in the professional and personal contexts ${ }^{(11)}$. Through human relations, nursing professionals deliver care to patients, participating in the emotions that emerge inside them, whether these refer to pain, discomfort, sadness, relief or hope, obliging professionals to be emotionally intelligent ${ }^{(12)}$.

Studies show that Mental Health nursing professionals have a higher average emotional intelligence level than the general population ${ }^{(13)}$. Mental
Health nursing professionals perform great emotional work in their daily practice by coping with problems like aggression, mistrust, depression or suicidal behavior. Emergence nursing professionals are immerged in a highly stressful environment, due to the times, work overload and contact with death. The meaning of emotional intelligence needs to be investigated in situations that are marked by great emotional work, like care delivery to patients who injure themselves or attempt to commit suicide ${ }^{(13)}$.

The objective in this study is to get to know nursing professionals' attitudes towards patients with suicidal behavior in two groups that have more contact with this kind of patients: emergency and mental health nursing professionals. Secondary objectives are to get to know whether the nursing professionals' Perceived Emotional Intelligence is related with a more or less favorable attitude towards suicidal behavior and the possible relation between this attitude and variables like the professional's gender, experience in care delivery to suicidal patients, mental health training, professional experience in nursing and time working at the same service.

\section{Method}

This descriptive and cross-sectional study incorporates a contrast of means to compare groups and undertake a correlational analysis of the variables involved, searching for associations. The reference population consists of baccalaureate nurses working at emergency and mental health services in the province of Granada, Spain and who are affiliated with the Servicio Andaluz de Salud $(\mathrm{N}=255)$. Data were collected in April, May and June 2011. In the end, 81 (31.8\%) nursing professionals participated, 52 working at emergency services and 29 at mental health services. Table 1 shows the participants' characteristics according to the study variables. Before distributing the questionnaires, permission was obtained from the nurse supervisors at each service and, at the centers where this was required, hospital management gave its approval. The questionnaires were distributed among the professionals at their place of work, where they were informed about the voluntary nature of their participation, confidentiality and anonymity. In addition, instructions were provided on how to complete the instrument and its future return, so as to permit completion beyond work hours. The selfadministered questionnaire consisted of 82 items and included the following measures: 
Cuestionario de Creencias Actitudinales sobre el Comportamiento Suicida or CCCS-18 ${ }^{(14)}$, which serves to evaluate attitudes towards suicidal behavior and is appropriate to discover how nursing professionals' position towards this fact, which is increasingly present in Spanish hospitals. In addition, this instrument offers the opportunity to further elaborate aspects that are closely related to nursing professionals, like the moral dimension and legitimacy of suicide and suicide in terminal patients. On the other hand, the instrument was created in Spanish and validated in a college population of Spanish nursing and psychology students. The CCCS-18's internal structure consists of four factors and a seven-point Likert scale, ranging from 1 (totally disagree) to 7 (totally agree). The first factor is called Legitimization of suicide and includes six items $(1,5,8,10,14$ and 18), related to the view of suicide as something rationally acceptable. The second factor refers to suicide in terminal patients and includes four items (2, 6, 11 and 15), related to suicide in people without any further possibilities to live. The third factor seems to indicate the moral dimension of suicide from a social perspective and consists of four items (3, 7, 12 and 16), scored inversely, so that high scores on these items refer to nursing professionals who disagree from these statements, while low scores refer to nursing professionals who agree. The fourth factor centers on suicide itself. This factor also includes four items (4, 9, 13 and 17) and indicates a view of one's suicidal conduct as an exit from a given situation.

The TMMS-24 (Trait Meta-Mood Scale)(15) questionnaire, which measures one's Perceived Emotional Intelligence or the ability to acknowledge, understand and regulate one's own and other people's emotions. This instrument has been adapted to Spanish(16) and consists of 24 items, with a five-point Likert scale ranging from 1 (strongly agree) to 5 (strongly disagree). In this scale, three factors are distinguished: attention, clarity and regulation. Attention refers to the ability to feel and express one's feelings adequately, acknowledging one's emotions and identifying one's own feelings. Clarity is related to the ability to integrate feelings in one's thoughts and understand the complexity of emotional changes. Regulation refers to effective and correct coping with positive and negative emotions.

In addition, a scale was included to measure social desirability or the need to get approval from subjects, responding in a culturally acceptable and appropriate way. The scale was developed by Crowne and Marlowe and adapted to Spanish by Ferrando and $\mathrm{Chico}^{(17)}$. It consists of 33 items, with forced answer options between right or wrong.
Together with the above instrument, an ad hoc questionnaire was used to collect data on the participants' sociodemographic variables.

Data were analyzed using Statistical Package for the Social Sciences (SPSS) software, version 18.0. Initially, the corresponding descriptive analyses were developed to get to know the sample's characteristics, as well as the scores obtained on the CCCS and its factors, TMMS and its factors and Social Desirability.

To contrast the results of the attitude questionnaire towards suicide, the sample was classified in groups according to the following characteristics: service the participant works for (mental health or emergency), genders (man and woman), experience with suicidal patients (yes or no), mental health education (yes or no) and duration of mental health education less than 30 hours or more than 30 hours. For the sake of these contrasts, Mann-Whitney's non-parametric U-test was used, due to the non-normal distribution of the scores in the moral dimension factor of the attitude questionnaire. To prove whether attitude towards suicide is related with the emotional intelligence level, besides other possible associations between the variables measured, Spearman's correlation test was used, as the normality requisite was not attended to.

\section{Results}

The results reflect that, in general, nursing professionals display negative attitudes towards suicidal behavior ( $M=65.31)$, although mean scores are higher among mental health professionals $(M=70.58)$ than among emergency professionals $(M=62.43)$. The third factor, "moral dimension of suicide", reveals mean scores ( $M=$ 21.89) that confirm that part of the nursing professionals reject the concept that suicide is immoral. Disagreement is common among nursing professionals for the factors "legitimacy of suicide" ( $M=16.30)$, "suicide in terminal patients" $(M=15.50)$ and "suicide itself" $(M=11.94)$.

Table 1 - Distribution of Participants among the Study Variables $(\mathrm{N}=81)$

\begin{tabular}{ll}
\hline & $\%$ \\
\hline Current service & \\
Mental health & 35.8 \\
Emergency & 64.2 \\
Gender & \\
Man & 28.4 \\
Woman & 71.6 \\
Professional experience (years) & \\
$\leq 5$ & 0 \\
$6-10$ & 3.7 \\
& (continue...)
\end{tabular}


Table 1 - (continuation)

\begin{tabular}{lc}
\hline & $\%$ \\
\hline $11-15$ & 12.3 \\
$16-20$ & 21 \\
$\geq 21$ & 63 \\
Experience at the service (years) & \\
$\leq 2$ & 33.3 \\
$3-8$ & 26.4 \\
$\geq 9$ & 40.3 \\
Mental health education & \\
None & 41.3 \\
Course $-30 \mathrm{~h}$. & 10 \\
Course $+30 \mathrm{~h}$. & 25 \\
Specialization in mental health & 23.8 \\
Experience with suicide & \\
Yes & 93.8 \\
No & 6.2 \\
No of suicide cases attended & \\
$\leq 10$ & 49 \\
11 -50 & 33.4 \\
$51-100$ & 3.9 \\
$\geq 101$ & 13.7 \\
\hline
\end{tabular}

Significant results in the intergroup contrast analysis are found in the "moral dimension of suicide" factor (Table 2), with strong rejection levels among mental health professionals $(U=326 ; p>$.001). Regarding gender, significant differences are found for "suicide is an immoral act" $(U=385,5 ; p<.01)$, with higher disagreement levels among women. Professionals with a mental health educational background significantly reject the item "Suicidal people are a threat to society" $(U=444 ; p<.01)$.

Significant differences between professionals who received more or less than 30 hours of mental health training appear in the "moral dimension of suicide factor" $(U=452.5 ; p>.05)$ and its items: "suicidal people are a threat to society" $(U=526, p<.01)$ and "suicide should be prohibited because it's murder" ( $U=521.5$, $p<.05)$. In all cases, disagreement levels from these assertions were higher among professionals with longer mental health training.

Table 2 - Comparative Analysis of Attitudinal Beliefs on Suicidal behavior among Emergency and Mental Health Professionals

\begin{tabular}{|c|c|c|c|c|c|c|}
\hline & \multicolumn{2}{|c|}{$\begin{array}{l}\text { Mental Health Nurses } \\
(n=29)\end{array}$} & \multicolumn{2}{|c|}{$\begin{array}{l}\text { Emergency Nurses } \\
\qquad(\mathrm{n}=52)\end{array}$} & \multicolumn{2}{|c|}{ Contrast test } \\
\hline & $\mathbf{M}$ & SD & M & SD & $\mathbf{U}$ & $\mathbf{p}$ \\
\hline \multicolumn{7}{|l|}{ Factors } \\
\hline Factor I: Legitimization of suicide & 16.67 & 8.74 & 16.12 & 8.45 & 689.0 & .893 \\
\hline Factor II: Suicide in terminal patients & 16.29 & 7.87 & 15.06 & 7.04 & 633.5 & .488 \\
\hline Factor III: Moral dimension of suicide & 24.46 & 4.55 & 20.36 & 5.63 & 326.0 & $.000^{\dagger}$ \\
\hline Factor IV: Suicide itself & 11.36 & 5.74 & 12.26 & 5.33 & 619.5 & .400 \\
\hline Total Attitudinal Beliefs & 70.58 & 20.42 & 62.43 & 19.52 & 390.5 & .078 \\
\hline \multicolumn{7}{|l|}{ Items } \\
\hline 1.Aceptaría ciertas formas de suicidio (ej.: sobredosis de pastillas) & 2.86 & 1.97 & 2.48 & 1.89 & 649.0 & .402 \\
\hline $\begin{array}{l}\text { 2. Debería permitirse el suicidio de una manera digna a las personas } \\
\text { con enfermedades incurables }\end{array}$ & 4.14 & 2.47 & 4.52 & 1.97 & 702.0 & .603 \\
\hline 3. El suicidio va en contra de la moral & 5.90 & 1.69 & 4.52 & 1.83 & 388.5 & $.000^{\dagger}$ \\
\hline 4. Es posible que me suicidara si estuviese en una situación extrema & 3.17 & 2.05 & 3.44 & 2.03 & 664.5 & .529 \\
\hline $\begin{array}{l}\text { 5. Si alguien quiere intentar suicidarse, es asunto suyo y no } \\
\text { deberíamos intervenir }\end{array}$ & 2.31 & 1.75 & 2.40 & 1.79 & 728.5 & .792 \\
\hline $\begin{array}{l}\text { 6. El suicidio es un medio aceptable de querer terminar con una } \\
\text { enfermedad incurable }\end{array}$ & 4.07 & 2.17 & 3.73 & 2.00 & 645.5 & .477 \\
\hline 7. El suicidio es un acto inmoral & 5.66 & 2.19 & 4.84 & 1.80 & 478.5 & $.007^{\dagger}$ \\
\hline 8. El suicidio debería ser una forma legítima de morir & 3.82 & 2.35 & 3.37 & 2.02 & 651.5 & .432 \\
\hline 9. Bajo ningún concepto me suicidaría & 3.86 & 2.15 & 3.87 & 2.10 & 747.5 & .948 \\
\hline 10. Aceptaría el suicidio en personas mayores & 2.66 & 1.83 & 2.90 & 1.91 & 682.0 & .465 \\
\hline 11. Es comprensible ayudar a suicidarse a un enfermo terminal & 3.59 & 2.29 & 3.80 & 2.09 & 677.5 & .528 \\
\hline 12. Los suicidas son personas que atentan contra la sociedad & 6.36 & 1.19 & 5.76 & 1.53 & 550.5 & .065 \\
\hline 13. Si me sintiese muy solo y deprimido intentaría suicidarme & 1.96 & 1.37 & 2.35 & 1.70 & 633.0 & .308 \\
\hline $\begin{array}{l}\text { 14. Debería haber clínicas para que los suicidas puedan quitarse la } \\
\text { vida de manera privada y con menos sufrimiento }\end{array}$ & 2.36 & 1.63 & 2.79 & 2.05 & 652.5 & .421 \\
\hline $\begin{array}{l}\text { 15. Aceptaría el suicidio en personas a las que les queda poco tiempo } \\
\text { de vida }\end{array}$ & 4.17 & 2.26 & 3.17 & 2.14 & 576.5 & 0.750 \\
\hline 16. Se debería prohibir el suicidio porque es un asesinato & 6.21 & 1.44 & 5.51 & 1.68 & 484.5 & $.022^{*}$ \\
\hline $\begin{array}{l}\text { 17. Algunas veces, el suicidio es la única vía de escape ante los } \\
\text { problemas de la vida }\end{array}$ & 2.34 & 1.85 & 2.48 & 1.76 & 663.5 & .346 \\
\hline 18. El suicidio sería una cosa normal en una sociedad ideal & 2.28 & 1.73 & 2.17 & 1.56 & 733.0 & .824 \\
\hline
\end{tabular}

$\mathrm{M}=$ Mean; SD = Standard Deviation; $\mathrm{U}=$ Mann-Whitney's $\mathrm{U} ; \mathrm{N}=$ sample; $\mathrm{p}=$ significance; $* \mathrm{p}<.05 ;+\mathrm{p}<.01$. 
After Spearman's test, the results reveal a positive and significant relation between disagreement from the immorality of suicide and higher scores on "Emotional Intelligence", "Emotional Clarity", "Emotional Regulation" and "higher educational level in mental health" (Table 3). A positive and significant correlation also exists between "social desirability" and "emotional intelligence" $\left(r_{\mathrm{s}}=.234 ; p<.05\right)$ and "emotional clarity" $\left(r_{\mathrm{s}}=.259 ; p<.05\right)$.

Table 3 - Results of Correlational Analysis between Moral Dimension of Suicide and Study Variables

\begin{tabular}{lc}
\hline \multicolumn{1}{c}{ Variables } & Moral dimension of suicide \\
\hline Emotional Attention & .037 \\
Emotional Clarity & $.287^{*}$ \\
Emotional Regulation & $.245^{*}$ \\
Emotional Intelligence & $.242^{*}$ \\
Social desirability & .224 \\
Professional experience & .003 \\
Experience at the service & .081 \\
Duration mental health education & $.270^{*}$ \\
No of suicide cases attended & .076 \\
\hline
\end{tabular}

$* \mathrm{p}<.05$

\section{Discussion}

Nursing professionals in this study share a negative attitude towards suicidal behavior. This result is in accordance with a society that, being mortal, rejects death, which is no longer admitted as a necessary natural phenomenon and is considered as failure, by society as well as by the health system ${ }^{(18)}$. Professionals with better acceptance levels of suicidal behavior reveal greater probabilities of positive health care delivery to suicidal patients ${ }^{(19)}$. Previous studies confirmed greater understanding of patients with suicidal behavior among mental health professionals ${ }^{(20-21)}$. Mental health nursing professionals have been trained to deliver care to psychiatric patients and are more confident to treat suicidal patients. Emergency care nursing professionals usually have neither formal training nor specialization to treat suicidal patients. One of the main reasons psychiatric and mental health care consumers identify not to seek or continue treatment is the stigma they are confronted with ${ }^{(8)}$. Inappropriate care delivery to patients with suicidal behavior can aggravate the situation that made them attempt to commit suicide and avoid health services on future occasions.

As shown among the women in this study, earlier studies have confirmed a more favorable and comprehensive attitude towards suicidal behavior among women ${ }^{(6)}$. In this study, nursing professionals with an educational background in mental health reject the moral aspects attributed to suicidal conduct, and rejection levels increase among professionals with longer training backgrounds. Previous studies have confirmed the importance of education to achieve more positive attitudes towards suicidal behavior(4-7) and the greater impact of more specialized education on attitudes ${ }^{(22)}$. Recommendations for health professionals to get education and training have been justified in countless studies $^{(4-21)}$, with a view to better self-knowledge on their perceptions and feelings, so as to permit a change in attitudes towards suicidal behavior. The inclusion of emotional intelligence competences in nursing curricula is recommended ${ }^{(12)}$

In this study, nursing professionals who are opposed to the immorality concept of suicide have a clearer view of their emotions and, in addition, are more capable of effectively regulating or repairing their emotions. In earlier studies, it has been demonstrated that people with higher scores on emotional clarity and regulation factors better tolerate stress, are more protected against burnout, feel more satisfied with their work, less anxious about death and their health is better ${ }^{(23)}$.

In self-reported measures like the TMMS-24, one of the difficulties patients present are social desirability problems, that is, that subjects respond with the social objective of transmitting a distorted image, whether positive or negatively. Answers on emotional intelligence in this study are influenced by social desirability. Nevertheless, even if non-voluntarily, subjects' subjective evaluation of their ability to manage emotions can cause perceptive and memory bias(24).

As a part of society and culture, nursing professionals have a range of attitudes and beliefs that affect their professional activities and, in turn, influence patients with suicidal behavior. Mistaken beliefs or myths towards suicidal behavior are also present in health professionals. One of the most frequently formulated examples is suicidal behavior as a "call for attention". Although not all people who attempt to commit suicide want to die, branding them as boastful is a mistake, as these are people whose useful adaptation mechanisms have failed and who do not find alternatives, except threatening their own life(25). Health professionals usually attempt "not to talk about suicide", so as not to encourage this conduct among patients. Instead of encouraging, provoking or putting this idea into the patient's head, however, talking about suicide with a 
person at risk reduces the danger of actually committing suicide and can be the subject's sole possibility to analyze his/her self-destructive objectives ${ }^{(25)}$.

\section{Conclusions}

Emotions and attitudes are important in nursing professionals' activities, which is why they need to be explored and readdressed, so as to achieve therapeutic actions involving patients with suicidal behavior. At the same time, nursing professionals' greater selfknowledge about their emotions would permit better management and reduce the stress and anxiety these provoke in health staff.

More effective management of suicidal patients brings down suicide-related morbidity and mortality rates and the essential element to achieve this is training about suicidal behavior.

The creation of protocols to guide and establish consensual criteria among health professionals with a view to making decisions on and managing suicidal patients, in hospitals as well as in outpatient care, would improve these patients' involvement and inclusion into the health network and their monitoring by community health professionals, with a view to preventing new suicide attempts.

\section{Limitations}

A non-probabilistic incidental study was undertaken, so that the results cannot be generalized to all nursing professionals.

The positive and significant correlation between perceived emotional intelligence and the social desirability scale indicate some kind of bias in the nursing professionals' answers.

\section{References}

1. Organización Mundial de la Salud (OMS). Prevención del suicidio: un instrumento para trabajadores de atención primaria de salud (Spanish) [Internet]. 2000. [acesso25 ago 2011]. Disponível em: http://www.who. int/mental_health/resources/preventingsuicide/en/ index.html

2. Bertolote JM, Fleischmann A. A global perspective in the epidemiology of suicide. Suicidologi. 2002;2:6-8.

3. Baca E. Intervenciones sobre poblaciones de riesgo. In: Bobes J, Giner J, Saiz J. Suicidio y Psiquiatría [Internet]. Madrid (ES): Triacastela; 2011. Chapter 6, Intervenciones sobre poblaciones de riesgo; [acesso 17 jun 2011]; p. 143-61. Spanish. Disponível em: http://www.fepsm.org/files/publicaciones/Suicidio_y_ Psiquiatr\%C3\%ADa-Texto.pdf

4. McCann T, Clark E, McConnachie S. y Harvey, I. Accident and emergency nurses' attitudes towards patients who self-harm. Accident Emergency Nurs. 2006;14:4-10.

5. Ross CA, Goldner EM. Stigma, negative attitudes and discrimination towards mental illness with the nursing profession: a review of the literature. J Psychiatric Mental Health Nurs. 2009;16:558-67.

6. Law GU, Rostill-Brookes H, Goodman D. Public stigma in health and non-healthcare students: Attributions, emotions and willingness to help with adolescent selfharm. Int J Nurs Studies. 2009;46:108-19.

7. Friedman T, Newton C, Coggan C, Hooley S, Patel $R$, Pickard $M$, et al. Predictors of A\&E staff attitudes to self-harm patients who use self-laceration: influence of previous training and experience. J Psychosom Res. 2006;60:273-7.

8. Sartorius N. Stigma and mental health. Lancet. 2007;370: 810-1.

9. Mininel VA, Baptista PCP, Felli VEA. Cargas psíquicas y procesos de desgaste en trabajadores de enfermería de hospitales universitarios brasileños. Rev. Latino-Am. Enfermagem. 2011;19(2):340-7.

10. Mayer JD, Salovey P, Caruso DR, Sitarenios G. Emotional intelligence as a standard intelligence. Emotion. 2001;1:232-42.

11. Fernández-Berrocal P. Inteligencia emocional para médicos del siglo XXI. El Médico. 2010;1112:22-5. Spanish.

12. Freshwater $D$, Stickley $T$. The heart of the art: emotional intelligence in nurse education. Nurs Inquiry. 2004;11:91-8.

13. Dusseldorp L, Meijel B, Derksen J. Emotional intelligence of mental health nurses. J Clin Nurs. 2010;20:555-62.

14. Ruiz-Hernández JA, Navarro-Ruíz JM, Torrente G, Rodríguez A. Construcción de un cuestionario de creencias actitudinales sobre el comportamiento suicida: el CCCS-18. Psicothema. 2005;17:684-90. Spanish.

15. Salovey P, Mayer JD, Goldman S, Turvey C, Palfai T. Emotional attention, clarity, and repair: exploring emotional intelligence using the Trait Meta-Mood Scale. In: Pennebaker JW. Emotion, Disclosure and Health [Internet]. Washington (DC): American Psychological Association; 1995. [acesso 9 abr 2011]; p. 125-54. Disponível em:

http://www.unh.edu/emotional_intelligence/EI\%20 
Assets/CognitionandAffect/CA1995SaloveyMayer.pdf

16. Fernández-Berrocal P, Extremera N, Ramos N. Validity and reliability of the spanish modified version of the Trait Meta-Mood Scale. Psychol Reports. 2004;94:751-5.

17. Ferrando PJ, Chico E. Adaptación y análisis psicométrico de la escala de deseabilidad social de Marlowe y Crowne. Psicothema. 2000;12:383-9. Spanish.

18. Tomás-Sábado J, Gómez-Benito J. Variables relacionadas con la ansiedad ante la muerte. Rev Psicol Gen Aplicada. 2003;56:257-79. Spanish.

19. McAllister M, Creedy D, Moyle W, Farrugia C. Nurses' attitudes towards clients who self-harm. J Adv Nurs. 2002;40:578-86.

20. Kishi Y, Kurosawa H, Morimura H, Hatta K, Thurber S. Attitudes of Japanese nursing personnel toward patients who have attempted suicide. Gen Hosp Psychiatry. 2011;33:393-7.

21. Patterson $P$, Whittington R, Bogg J. Measuring nurse attitudes towards deliberate self-harm: the Self-Harm Antipathy Scale (SHAS). J Psychiatr Mental Health Nurs. 2007;14: 438-45.

22. McCarthy L, Gijbels $H$. An examination of emergency department nurses' attitudes towards deliberate selfharm in an Irish teaching hospital. Int Emergency Nurs. 2010;18:29-35.

23. Augusto JM, López-Zafra E. The impact of emotional intelligence on nursing: An overview. Psychology. 2010;1:50-8.

24. Extremera N, Fernández-Berrocal P. El uso de las medidas de habilidad en el ámbito de la inteligencia emocional. Bol Psicología. 2004;80:59-77. Spanish.

25. Rueda F. Guía sobre la prevención del suicidio para personas con ideación suicida y familiares. [Internet]. 2010. [acesso 17 jun 2011]. Spanish. Disponível em: http://feafes.org/guia-sobre-la-prevencion-del-suicidiopara-personas-con-ideacion-suicida-y-familiares/ 